Pakistan Journal of Humanities \& Social Sciences Research Volume No. 02, Issue No. 01(June, 2019)

\title{
THE ROLE OF RULE OF LAW IN THE ESTABLISHMENT OF A CIVILIZED SOCIETY: AN ANALYSIS OF PAKISTAN
}

\begin{abstract}
Imraz Muhammad* \& Dr. Arif Khan**
Abstract:

Unsurprisingly, human being needs smooth, peaceful and a regularized system not only to survive, but to live well. To get $i$, human being has been continuously struggling since early times. Many written and unwritten efforts in this regard are found among which, the first written one is the Magna Carta of 1215. The Article 39 of the Magna Carta (1215) declared, "no freemen shall be taken or imprisoned or diseased exiled or in any way destroyed, nor will we go upon nor send upon, except by the lawful judgement of his peers or by the law of the land". Ibn-e-Khaldun opines that the construction and deconstruction of society depends upon law. If on one hand, obedience of law rises empires then discarding it is equal to digging grave for empires. Sustainability of civilization is subject to rule of law. Those societies which follow laws strictly in their daily routine they are in the line of developed nations. Today Europe is in the epoch of greater civilization because they adopted the rule of law in its true spirit. Once Muslim world was civilised one until they believed on rule of law, equality and justice but fell down when started disobeying the principles of the rule of law. Since its very inception, "might is right" is the prevailing phenomena everywhere in Pakistan. Each and every department and even on individual level, the rule of law is not respected. No one cares to respect and follow rule of law that is why we could not determine our destination. The main objective of research study is to find out what role can the rule of law play in establishing a civilized society in the context of political, social and economic norms. In addition, this research study will also bring to surface the impacts of disobeying of rule of law, on political, social and economic rights of individuals in Pakistan.
\end{abstract}

*Lecturer in Political Science, University of Buner, Buner, KPK.

Corresponding author: imraz.mohmand@gmail.com

**Assistant Professor in Political Science, University of Buner. 
Keywords: Pakistan, rule of law, society and moral value.

\section{Introduction}

What is "rule of law"? Here is the definition: rules and laws which abide and bound common civilian and governmental officers (Tamanaha, 2012, p. 233). But actually rule of law is more than that as stated by the Helen Yu and Alison Guernsey; in the foremost basic sense rule of law is a system which prohibited rulers and citizens from arbitrary and abusive use of authoritative powers (H. Y. all, p. 1). While the English writer, A.V. Dicey define as, supremacy of the law which opposed to the influence of each arbitrary power and excluded all arbitrary power which have illegal existence of the discretionary power over government. Furthermore, rule of law equality before which, each individual or group of individual or any other institution is bound to ordinary law of the land (Principe, 2000, p. 359).

The rule of law seems as a term, which comprehends all aspects of the individual i.e. political, social or economic. It protects rights of the individual from the humiliations on the hands of arbitrary king or other authoritarian office. In political sphere, it is the rule of law which focus on freedom of thought, freedom of expression, right to make a political party, right to vote, right to contest election and right to constructive criticism etc. While in economic sphere it is rule of law which provides equal opportunity for job, equal distribution of resources, equity, no one can engulf the property of other by force etc. Social rights or human rights such as right to free movement, right to life, right to family, prohibition of slavery, and other fundamental rights are protected by the rule of law.

Protection of the individual rights is the essential condition for a civilized society. It is the rule of law which protect the individual rights, freedoms, liberty and provide and ensure such an environment, where individuals can improve their living standards (Tamanaha, 2004, p. 1). Society that is run by law and not by the arbitrary power of the absolute authority, that may reach to the epoch of civilization and development while in contrast a society which is run through the sole power of the persons, and where the citizens are considered as slaves that may not run for long period of time. History is full of various revolts against king because of the arbitrary use of powers against their subjects. 
This work elaborated what is the rule of law? Does rule of law make society a civilize one? To what extent did the rule of law protect the political, social and economic rights of individual in Pakistan? Probably in the society of Pakistan, most of the political, social and economic rights of the citizens are violated and it is because the rule of law is not followed in real sense.

\section{The Role of Law in the Construction of Society Part-A: Interpretation of the Rule of Law in the Perspective of Political, Social and Economic Rights:}

The $21^{\text {st }}$ century is witnessing the defeat of the Hob's terror society (Hobbes, 1651) i.e. the abolition of king's discretionary powers, feudalism and dictatorship. While most of the states have been focusing on the concept of welfare state where democracy, liberty, freedom and rule of law are given preference. This concept of righteousness and peace might be possible because of the rational and mature political culture of individual. To boost the growth of society (politically, socially and economically), it is necessary to follow the rule of law. So, in light of the mentioned statement, out all the important aspects of individual life:

[The "rule of law"] refers to a principle of governance in which all persons, institutions and entities, public and private, including the State itself, are accountable to laws that are publicly promulgated, equally enforced and independently adjudicated, and which are consistent with international human rights norms and standards. It requires, as well, measures to ensure adherence to the principles of supremacy of law, equality before the law, accountability to the law, fairness in the application of the law, separation of powers, participation in decisionmaking, legal certainty, avoidance of arbitrariness and procedural and legal transparency (Council, 2004, p. 4).

In the light of the above definition, the construction of a civilized society depends upon rule of law. A society which follows the values and norms of the rule of law is considered to be a civilized society but the question is what sort of the rule of law i.e. what should be its boundaries, either it should be limited only to the Article 39 of Magna Carta Act of (1215),"No freemen shall be taken or imprisoned or diseased or exiled in any way destroyed, nor will we go upon him nor send upon him, except by the lawful element of his peers or by the law of the land" (Carta, n.d,pp. 11-12), either it should be more than that. Clearly, this definition is limited only to fundamental 
rights of individual while rule of law is wider in its sphere of rights as political, social and economic rights of individual come under it. In this practical age, human rights demands for the welfare and civilized society that is free of war, tyranny and centralization of powers, and probably belief on individualism. This is possible only to expand boundaries of the rule of law in political, social and economic perspective.

In political sphere, rule of law must protect democracy, liberty, equality, freedom of thought and expression, right of universal franchise, separation of powers, autonomy of the provinces, independence of judiciary etc. These rights should be protected through rule of law. Protection of the rights leads to good governance, which is impossible without rule of law. It is rule of law that makes every one equal and provides equal opportunity of justice in a democratic society and gives birth to a politically mature society in the shape of good governance. Where political leaders are responsible, political stability and absence of conflicts, control over corruption, effective policies and more than that are followed because of the rule of law (USCIB, 2015, pp. 3-4). These are the rights for which people struggle to get for a long period of time. Demands for these rights changed the absolute monarchy of United Kingdom into constitutional monarchy during Glorious Revolution 1688 and passing the Bill of Rights 1689 (Bill of Rights 1689). French Revolution of 1789 was a consequence of not providing political rights to individual (Revolution 1789), (Kropotkin, 2009).

The norms of society depend upon human rights, the agreements of Locks, Rousseau and Ibn-e-Khaldun about state and government depends upon rights of individual. Peace in society could be possible only if rights provided to individual without particularism (colour, cost, religion, language, nation, class or any other character). There should be focus on universalism. For ensuring peace on earth it is necessary to respect human rights and here Islam is the first to give fundamental rights to individuals (Maududi, n.d.). Not only Islam but the west also believes in Individual rights and acknowledged that maintenance and balance of the society depends upon human rights and that is why they passed so many declaration in the shape of "The Universal Declaration of Human Rights 1948 (UNDHR)", "International Covenant on Civil and Political Rights 1966 (ICCPR)", and "International Covenant on Economic, Social and Cultural Right (ICESCR)". These contained on rights of life, free movement, religion, 
family, security, respect of women, basic standard of life, justice, equality, equity, fraternity, penalty for wrong doing and rewards for doing good, protection of minors, fair trial, no deprivation and degradation and cooperation etc. (The Constitution of the Islamic Republic of Pakistan n.d.), (M. Glen Johnson, 1998, pp. 11-108), (PWESCR, 2015, pp. 5-42), (Maududi n.d.), (ICCSCR 1966), (al-Sheha n.d, pp. 47-91). Whenever these fundamental rights are provided to any society, there would be no conflicts and peace would be established.

Economy have great role in the development of society. Sustainable development depends upon the growth of economy. Generally, economic growth depends upon, capital, resources, physical and mental powers, skilled labours, demands and supply, good policies, best environment and jobs opportunity etc. (Motelle n.d: 2). But it might possible in those societies, which keep the economic rights of individual for instance, rights to job, earn, selling and buying, trade, job security, (Bulmer, 2014, p. 7), (ICCSCR 1966), (Maududi n.d.), Although these are the factors which bring peace, prosperity and economic growth in a society, but actually, economic growth without rule of law is a myth, because bases of the economic growth rested on justice, which is imposed equally for entire, without discrimination, colour and cost (Dam, 2006, p. 16).

Political responsibility, economic growth and resources, skilful labour, development of the institutions and justice, these are the most important factors which rise and fall a civilized society, but the protection of these norms depends upon rule of law. It is rule of law that makes the political authorities responsible to individual and distributes the national resources on equal basis. Furthermore, it is rule of law which cleared the position of institutions and explains rights and duties of individual. Khaldun's discourses on economic development clearly mentioned that justice is the most important factors which bring transparency and development (Chapra, 2008, pp. 836-863).

Part-B: The Status of Rule of Law in Pakistan: In the Analytical Perspective of Political, Social and Economic Rights:

Rule of Law and Political Rights in Pakistan:

A mature political society is one where democracy is followed, government is always responsible to people, where there is respect for leaders, elections are free from rigging, respect for 
the vote, freedom of thoughts and expression, respect for the public opinion, separation of powers, respect for constitution, respect for the rights of minorities, independence of judiciary, independence of press and media, all of these are political rights which must be followed in a democratic system of society. Specifically, these rights are protected in a society where there is rule of law and society runs on the back of law. When law subordinate to individual or an institution, that society may fall into the lap of destruction and political rights are engulfed. So, the question is whether the rule of law protects the political rights of individuals or not in the above mentioned scenario, if not, so, what are the factors which makes a politically handicapped society in Pakistan.

\section{Politics:}

The establishment of civilised society depends upon rule of law and good governance. Government which has the capacity of justice, charismatic leaders, and development of the institutions, advocate economic system and resources, peoples have skill and followed the rule of law is a civilized society. Furthermore, it is necessary for the good governance that society should be free from corruption, no absolutism of one man or family over politics and economy of state, popular democracy should be maintained in the territorial boundary, government must be responsible, participation of individual in government, equity and equality, consensus and cooperation and there is a separation of powers in governmental institutions (Graham, 2003, pp. 1-6) (Chapra, 2008, pp. 836-863). The role of the rule of law in a political setup is to create a responsibility, where the leaders are responsible to individual and citizens have direct involvement in decision making, as the society of Switzerland is abide in this sphere. But in case of Pakistan, the role of the rule of law is freezes because of the immaturity of the politicians.

\section{Politicians:}

Political history of politicians in Pakistan are full of malwares and silly facts, most of them work for their own interest rather for the welfare of the state and so, Quaid e Azam declared that I have rough coins in my pocket. Feudal lords and industrialists have control over the centre and provinces, political leaders are subject to them because they economically supported politicians in needs (Nawaz, 2015, pp. 19-22). Initially, there was a parliamentary form of government in Pakistan, so in such 
system head of the state is titular and have no constitutional rights to interfere in political sphere but due to weak democratic system during 1950-56, the then heads of the state Ghulam Mohammad and Iskindar Mirza, they were practically involved in the parliamentary setup (Nawaz, 2015, pp. 19-22). So, due to the political immaturity of the politicians, military coup d'état took over the government. It was not much time that to take the snare of government by the civilian, political leader divide state into two parts (A. P. all n.d, pp. 31-43). Same the situation was there in the 1990 decade, leaders of the PPP and PML were in opposition, there were no cooperation and tolerance and democratic governments were break down so many times. Actually, there is political instability in Pakistan since its inception and it have so many reasons, like political immaturity, lack of awareness and education, military intervention, corruption but the foremost one is the lacking of the rule of law. Politicians done only work for their own interest as in 1970 election Mujaib has clear majority but Z.A. Bhutto never agrees to share powers and orders to their ministers that he would break their legs if any one go to assembly (Khan, 2005). (This reference is not included in the basic list) Not only this, there is also the problem of hereditary leadership i.e. only Bhutto family have control over PPP, Nawaz family have control over PMLN party. So in real sense there is parochial and concept democracy, not a real representative democracy.

\section{Military:}

Pakistan has experimented of frequent coups d'état and political instability since its inception. In military takeover, General Ayub Khan was the first military dictator who took control over the government in October 7, 1958, and continued his reign till 1968. In 1969, General Yahya Khan got government charge without any delay, he maintained possession till 1971. Among this race, General Zia-ul-Haq (1977-1988) was the third one who maintained power and the fourth one General Pervez Musharaf (1999-2001) (Dawood, 2014 , p. 283). Now the question is why did military coup take place in Pakistan? The basic reasons of military intervention in politics are weak political system, corrupt political leaders, immaturity of the citizens in politics and the foremost one lacking of the rule of law. It is rule of law that keeps everything in an ordered form. Aisha Saddiqa declared in Military Inc that the military has great share in economy of Pakistan (Siddiqa, 
2007), and it is the reason to have control over power. Military involvement in politics establish nightmare for the rule of law, because rule of law demands for the maintenance of political stability, democracy and rule by law. While political stability, good governance and specially rule of law, these are the best barrier for the military d'état. But unfortunately, the lacking of the mentioned factors in Pakistan level the way for military coup. Army attachment in professionalism, politics and economy compel military to have direct or indirect control over the government.

\section{Elites:}

Pakistan's political structure is pluralistic, having no clear and single elites to control power. Different elites groups like military elites (ME), bureaucratic elites (BE), industrial elites (IE), professional elites (PE), religious elites (RE) and landowning elites (LE) control over the political system of Pakistan (A. Hussain, Elites and Political Development iin Pakistan 1976: 224). Each elite fiction has their own concept and ideologies and wanted to run the state according their own ideologies. The ME wants praetorian state, the LE interested feudal setup state, the BE focus on administrative state, the IE leads to bourgeoisie state, the PE want to realized the dream of democratic state and RE solely interested in religion state (A. Hussain, Elites and Political Development in Pakistan, 1976, p. 233). It means that Pakistan is laboratory, where each one tests their own concept and ideologies while the rule of law demands cleared the system of responsibility, which is run on the interest of citizens. Mentioned elites neither accept each other nor tolerate for each other, this is the reason there is political instability since its inception.

\section{Election Rigging:}

It has been declared in Article 21 of the Universal Declaration of Human Rights that the determination of the citizens "shall be expressed in periodic and genuine elections which shall be by universal and equal suffrage and shall be held by secret vote or by equivalent free voting procedures", Article 226 of the 1973 constitution of Pakistan also focused on the secret ballot of the universal franchise, which should be free from any malpractices. In a democratic society, there is a periodical election in which public choose their own representative for the purposes to have a political representation on national level, 
control over political powers, promulgate their own charter and program and give a practical shape to their ideas (Wojtasik, 2013 , p. 28). Unfortunately, there are rigging and fraud in election by the political parties to win election. For their own interest political parties hide public mandate and charters. Unluckily, Pakistan is the victim of electoral fraud, rigging and malpractices. Since 1947 to 1970, there were not general elections in the history of Pakistan. The first ever elections were held in 1970, although, the elections were won by the Awami League but power did not share with them (Khan, 2010, p. 168). Second general elections were held in 1977, won by the Z.A. Bhutto, but it was highly rigged and caused serious protest across the state run by the Pakistan National Alliance (PNA) (Khan, 2010, p. 168), consequently, state fell into the sphere of military dictatorship. After a long period of General Zia ul Haq regime, power shifted to civilian government, in this decade a quarter elections took place between PPP and PML, but due to corruption and lack of political maturity a military took over the government in 1999. In short, there was not only rigging in past but the elections of 2008, 2013 and 2018 are still the victim of rigging. However, norms and values of the rule of law are absolutely against doing frauds and rigging in elections. It is order for the transparent and pure elections which never disturb ideologies and charters of citizens. Because through elections public do change their fate, but unfortunately such a democratic system dump in Pakistan.

\section{Rule of Law and Economic Rights in Pakistan:}

Today, develop nations have control over rest of the world because of the sustainable development in economic field and maintenance of the rule of law. It is rule of law, which investigated and enforces the rights and duties of individual, institutions and state. Rule of law prohibits interference in each other rights, because it is nature of justice to keep everything in his own place. Arguably, Thomas S. Ulen, clearly mentioned in The Role of Law in Economic Growth and Development (Ulen, 2011, pp. 2-40) that some nations got economic development while mostly nations are decreasing. In 1800, United Kingdom was the world richest country because it had an average per capita income; while in poor side there is Africa (Ulen 2011: 240). United State of America has increased its per capita income increased 25 fold, Western Europe got 15 times (Ulen, 2011, pp. 2-40), China and India also have been increasing their GDP and PCI but in confrontation, some of the nations 
like Pakistan have low PCI. In one report of the World Economic Forum, Pakistan was got at 124 among 144 nations (Asghar, 2013, p. 113). Now the question is, why some of the nations have high GDP and PCI while some nations have low? It is stated that the most developed nations followed the true nature of law, they find the key of success by the adaptation of the rule of law, which demands for the equity, justice, merit, and equal distribution of economic resources. So, any society which confiscated on the true nature of the rule of law they get development in economic sphere. However, it is very surprising that how little Pakistan knows about the rule of law and its effects on economic growth.

Rule of law demands for the economic equality, unfortunately, feudal and capital class of Pakistan have control over the national purse of sources (khans, wadheras, rajas, chudhaies, and malaks). Natural gas and hydroelectric power have great share in the development of the Pakistan's economy. The bulk of these sources are located in Baluchistan and Khyber Pakhtunkhawa respectively but unfortunately both the provinces are underdeveloped while the profits of these energies go to Punjab and Sindh. Out of 26 districts only 4 districts have access to natural gas in Baluchistan. It was supplied so, to meet the demands of the military cantonment (Meezan Z Khawaja, 2009). Like Baluchistan, Khyber Pakhtunkhawa has the same fate, most of the hydel power are produced in KPK. Until 1991-1992 KPK did not receive any royalty in substitute of hydel power. In 1991-92 the government of KPK received 5.99 billion as a net profit for hydel power from the central government. Later on, it was increased to 6 billion (Meezan Z Khawaja, 2009). However these are the situation of mineral and resources, which snares are in the hands of elites, and these are used by them according to their own mean. As a result, poverty is increased day by day in Pakistan, and especially Baluchistan and KPK are in its trap. Poverty caused terrorism and insurgency in Pakistan which destabilized the socio-economic development.

State is responsible to provide the facilities of protection, health, education, infrastructure, justice etc. but in contrast demands from public to help the state in the shape of taxpaying. It is the tax which runs the state in a smooth way, no one state is exempted from it because it is the source of development. Unfortunately, Pakistanis is the 2nd lowest in Asia in the overall tax paying category, behind Bangladesh and Sri Lanka in tax paying countries (Rahman 2018). Corruption in tax 
paying has so many reasons, i.e. the Federal Board of Revenue is consider one of the main corrupt institute in Pakistan (all, 2014, pp. 50-69), discrimination in tax paying by the officers, amnesties from tax, anti-tax culture, exempted areas and institutions etc. are the basic barriers in tax paying. While rule of law demands to pay tax on equity basis, because, it is the sources of growth for the state.

Rule of law also focus on friendly environments, where there is not only the absence of conflicts and violations but also free from pollutions (air, water and soil). Pakistan Environmental Protection Act (PEPA), 1997 and The Environment (Protection) Rules of 1986, demand for a safe heavens society, which is free from any type of contaminated and polluted material. These are the laws which restore a healthy and friendly environment but unluckily, it is only limited to documents not in practice. Marble factories and glass factories dropped its waste material in sea water, which is harmful for water animal and agriculture. Contaminated water causes serious diseases like diarrhea, typhoid, dysentery, gastroenteritis etc. these are very common in Pakistan. In 2006, 4.5 million cases of diarrhea were reported, about 230,000 infants die every year in Pakistan because of the water pollution (all, 2014, p. 13936). Solid waste material is also cause of different diseases, solid dumps blocked drainage systems which assist flies nurturing, rats, vermin and causing of toxic gases etc. (N. E. all, 2010, pp. 379-387). So, law has declared rules and principles for the creation of friendly environment but now it is on individual that how it comes to it.

\section{Rule of Law and Social Rights of Individual in Pakistan:}

Social rights are the human rights, which are fundamental and related to everyone. Social rights like justice, equality, life, family, relations, freedom of thoughts, expression, fairness etc. are almost same everywhere. For welfare of society, it is necessary to protect all of these rights of individual because it is real not abstract. In a modern concept, the 1973 Constitution of Pakistan and Universal Declaration of Human Rights provided a huge list of human rights which is included life, free movement, religion, family, security, respect of women, basic standard of life, justice, equality, equity, fraternity, penalty for wrong doing and rewards for doing good, protection of minors, fair trial, no deprivation and degradation, cooperation and more (The Constitution of the Islamic Republic of Pakistan n.d.), (Johnson, 1998, pp. 11-108), (Pakistan Law on Human Rights 
n.d.). Although, all of these rights are enlisted in 1973 Constitution but the question is, these are follow in daily life or not or law assure the protection of the social rights of the individual.

Social rights or human rights violations are very common in Pakistan. Press media published torture of the innocent people, extra judicial killing, women beating and killing and gender discrimination, kidnapping, cruelty of the police, nuisances, religion discrimination, children abuses, bomb blasting, mismanagement for refugees and internally displacement people etc. on daily bases. All of these are daily watched inside Pakistan, it is because of the lacking of the rule of law, which means law is not followed in real sense. In case of the violation of the rule of law, not only government is responsible but a common man also. Pakistan is a developing nation this is why it may not effectively fulfil basic needs of their citizens i.e. lack of education, good health, and adequate opportunity for job. That is the genuine reasons of terrorism, kidnapping, nepotism, corruption, masses nuisance and violation of the rule of law.

Education have great role in establishing of civilization and rationalization of society, as we have the example of Europe, USA, Canada, Japan, China in current scenario while in passed there were Muslim reigns. Unfortunately, Pakistan is behind in this race not only from develop but from developing nations also. According to one report of the Human Rights, less than $60 \%$ of Pakistanis are literate. Although, more than 50\% literates are living in urban areas, this figure decreased to $20 \%$ and $10 \%$ in rural areas i.e. Baluchistan, Sindh rural, FATA etc. (Pakistan n.d.). Although the 1973 constitution demands for free education from six to sixteen (The Constitution of the Islamic Republic of Pakistan n.d.) and have done much and doing but still the rural areas are victim of illiteracy.

Rule of law also demands for the good health facilities, hospitals, play grounds and entertainment places for the citizens. Most nations provided a vast part of their gross domestic product GDP for the health care. But the situation in Pakistan is different, provided only $1.3 \%$ of its GDP (Pakistan n.d.), which is less than South Asian regional states. As result, people face different diseases.

It is a general phenomena that economic growth bring stability and peace, as the MacDonald and multinational companies have great markets in peaceful areas for example in Europe, USA, Canada, Saudi Arab and UAE it is because of the stability and peace, while rarely or not available in Palestine, 
Afghanistan, Yemen etc. it is because of the war, insurgency, violations and conflicts in the mentioned areas. So probably it is stated that peace and economic growth are necessary for each other. Over recent years, poverty is increased and the opportunity of economic growth decreases day by day, circular debits and IMF debits reach to its peak, as result taxes increases and become headed for the poor class. According to Islamabad based Pakistan Poverty Alleviation Fund, a semi-autonomous, World Bank Funded Organization, 32\% of Pakistanis are living in poverty (Pakistan n.d.) Its main cause of the violations of the rule of law, that is discrimination in Baluchistan and KPK as mentioned in above lines.

Criticized over the uniformity of laws and its enforcement, Human Rights and Pakistan- An Overview stated, although Pakistan signed the charter of the UDHR, but still much of its parts are not followed, which is violation of the rule of law. Pakistan denies and ignores rights of children to education (Pakistan n.d.), women rights are still victim of discrimination. Human rights violations are very rare situation in Pakistan, in Daily routine news papers published the news of children and women abuses and trafficking, violation of the transgender, killing of the actors and singers, police discriminatory policies, poverty and other violation of the social rights converted the civilized citizens to terrorist, thieves and underworld violins.

\section{Conclusion:}

Developing nations are struggling to adopt the rule of law while developed nations are trying to preserve and maintain it. It is because the rule of law has the potential to ensure prosperity and development if adopted in its real sense. As for as Pakistan is concerned it lacks some essential factors/requirements such as absence of good governance, independence of Judiciary in a real sense, military intervention in politics is common, rampant corruption on the part of politicians and also other government officers, delay in administering justice, elites control over politics and economic resources, insecurity, terrorism, nepotism, immature political culture, lacking of democracy and unawareness, lacking of education, lacking of the constitutional supremacy and prevailing of dynastic politics. The mentioned terms are lacked in the society of Pakistan in their true sense. That is why our society is faced with a political instability, increasing poverty, debits rising, lacking of energy not to mention all. Such sort of situation is because of the inefficient 
policies of the government which in turn is because of poor rule of law in Pakistan.

\section{References:}

Awan, A. G. et al. (2014). The Determinats of Tax Evision in Pakistan: A Case Study of Southern Punjab. International Journal of Development and Economic Sustainability. pp.50-69.

"Bill of Rights" (1689). Retrieved: www. law. gmu. Edu /.../ English_BillofRights.pdf..

Bulmer, D. A \& Elliot. (2014). "Social and Economic Rights." International Institute for Democracy and Electoral Assistance (International IDEA), P. 7.

Chapra, M. U. (2008). “Ibn Khaldun's theory of development: Does it help explain the low performance of the presentday Muslim world?" The Journal of Socio-Economics 37, pp. 836-863.

Dam, K. W. (2006). The law growth Nexus: The rule of law and Economic Development. Washingtoon D.C.:

Brooking Institution Press Washington D.C., p. 16.

Dawood, M. (2014). "The Causes of Military Intervention in Politics: A Case Study of Pakistan and Bangladesh." European Scientific Journal August 2014 /SPECIAL/ edition, p. 283.

Ejaz,N., et al. (2010). "Environmental Impacts of Improper Solid Waste Management in Developing Countries: A Case Study of Rawalpindi City." WIT Transactions on Ecology and the Environment, Vol 142, WIT Press, pp. 379-387.

Farhat Nabeela. et al. (2014). Microbial Contamination of Drinking Water in Pakistan-a review." Springer-Verlag Berlin Heidelberg, pp.13929-13942.

Graham, J. (2003). "Principles for Good Governance in the 21st Centuary." Institute On Governance (IOG), pp. 1-6. Retrieved:

https://www.google.com/search?q=\%E2\%80\%9CPrinciples 
+ for+Good+Governance+in+the+21st+Centuary. $\%$ E2\%80

$\% 9 \mathrm{D}+$ Institute+On+Governance+(IOG\&oq $=\% \mathrm{E} 2 \% 80 \% 9 \mathrm{C}$

Principles+for+Good+Governance+in+the+21st+Centuary. $\% \mathrm{E} 2 \% 80 \% 9 \mathrm{D}+$ Institute+On+Governance $+(\mathrm{IOG} \& \mathrm{aqs}=\mathrm{chro}$ me..69i57.1472j0j7\&sourceid $=$ chrome $\&$ ie $=U T F-8$

Hobbes, Thomas.(1651).Leviathan. London: printed for Andrew Crooke, at the Green Dragon in St. Pauls Churchyard.

Hussain, A. (1976). Elites and Political Development in Pakistan. The Developing Economies, 14(3).233. Retrieved: www.deepdyve.com/lp/wiley/elites-and-political,

Helen, Yu. et al. (n.d.). "What is the Rule of Law?" World Bank, The Rule of Law as a Goal of Development Policy Source.

Retrieved: http://www.uiowa.edu/ifdebook/faq/Rule_of_Law.shtml, :1, pp. 1-9.

ICCSCR. (1966). International Covenant on Economic, Social and Cultural Rights. Retrieved: www.ohchr.org/Documents/ProfessionalInterest/cescr.pdf,.

Khan, I. H. (2010). "Electoral Malpractices in Pakistan: A Case Study of the General Elections 2008." Pakistan Journal of History and Culture,31(2), 168.

Kropotkin, P. (2009). The Great French Revolution 17891793. New York: New York: Vanguard Printings.

M. G. J., et al. (1998). The Universal Declaration of Human Rights: A History of its Creation and Implementation 19481998. France: United Nations Educational Scientific and Cultural Organization, pp. 11-108.

Maududi, S. A. A. (n.d). Human Rights in Islam. Retrieved: www.muslimlibrary.com/.../English_Human_Rights_in_Isl am.pdf.

Maxeiner, M. S. \& James R. (2010). The Rule of Law in Comparative Perspective. New York: Springer Dordrecht Heidelberg London New York, p. 1. 
Meezan, Z. K, et al. (2009). "Natural Resources Allocation in Balochistan and NWFP: Reasons for Discontent." Sustainable Development Policy Institute SDPI, pp. 1-16.

Motelle, M. S \& Sephooko. (n.d). "Sources of Economic growth the Southern African Development Community: Its likely Impact on Poverty andEmployment." Retrieved: www.sadcbankers.org/Lists/News and Publications.

Nawaz, A. (2015). "Political Instability in Pakistan 19471956." International Journal of Art \& Humanity Science (IJAHS) e-ISSN: 2349-5235, pp. 19-22.

Pakistan Law on Human Rights. (n.d.). International Human Rights Observer. Retrieved: https://www.google.com/search?sxsrf=ACYBGNR_r1Jdjag 1am2MCiPtDmMD23dwQ\%3A1568980039859\&ei=R7yE XdmPNKSalwTS27JY\&q=International+Human+Rights+ Observer.\&oq=International+Human+Rights+Observer.\&g s_l=psy-ab.3 ..0i22i $3015.823305 .823 \quad 305 . .8244$ 86...0.0 ..0.287.287.2-1.....0....2j1..gws-wiz .BI Inzrl jLV s\& ved $=0 \mathrm{ah}$ UK EwiZ z72Pqt _kAhU kzYUK HdKtDA sQ4dUDC As\&uact=5

Pakistan, Voicing Issues of Victims of Human Rights Violations in. "Human Rights \& Pakistan - An Overview."

Pervez, A. et al. (n.d. ). Political Instability: A Case Study of Pakistan. Journal of Political Studies, 18 (1), 31-43.

Principe, Michael L. (2000). Albert Venn Dicey and the Principlesof the Rule of Law: Is Justice Blind? A Comparative Analysis ofthe United States and Great Britain. Loyola of Los Angeles International and Comparative Law Review, pp. 357-73.

PWESCR. (2015). International Covenanton Economic, social and Cultural Rights: A handbook. New Delhi: PWEsCR (Programme on Women's Economic, social and Cultural Rights), PP. 5-42.

Rahman, A. (2018). Pakistan Falls Lower In Latest Tax Collection Rankings. Retrieved: 
propakistani.pk/2018/12/07/pakistan-is-below-sri... $\quad$ ProPakistani.

Salik, S. (n.d.). Main ne Dahka Doobti Dekha

Secretary-General to the Security Council. (2004). "The Rule of Law and Transitional Justice in Conflict and PostConflict." (United Nations Security Council, S/2004/616*), p. 4.

Sheha, Rahman. A. (n.d). Human Rights in Islam and Common Misconceptions. Retrieved: hrlibrary.umn.edu/research/Egypt/HumanRightsinIslam.pdf, pp. 47-91.

Siddiqa, A. (2007). Military Inc: Inside Pakistan's Military Economy. New York: Oxford University Press.

Tamanaha, B. Z. (2004). On the Rule of Law, History , Politics, Theory. New York: Cambridge University Press.

Tamanaha, B.Z. (2012). The History and Elements of the Rule of Law. Singapore Journal of Legal Studies, 232-247. Retrieved from https://pdfs.semanticscholar.org/bfbc/80a72d22d5faae8605 882f1068419d035a0c.pdf

"The Magna Carta (The Great Charter)". (n.d)." National Public Telecomputing Network (NPTN). Retrieved: liberalarts.utexas.edu/coretexts/files/resources, PP. 11-12.

The Constitution of the Islamic Republic of Pakistan.

The Environment (Protection) Rules 1986. (1986). New Delhi: New Delhi, Retrieved: https://www.google.com/search?sxsrf=ACYBGNQ8dE_DTevRH nnJboJ5nAiknC_Frw\%3A1568981136556\&ei=kMCEXfDNIcWJIw TQ0bL4Dg\&q=The+Environment+\%28Protection\%29+Rules+19 86.+\&oq=The+Environment+\%28Protection\%29+Rules+1986.+ \&gs_l=psyab.3..0i22i30l10.101795.101795..102666...0.4..0.296. 296.21.....0....2j1..gwswiz......0i71.qLaYxAzw7X4\&ved=0ahUKE wjw1baart_kAhXFxIUKHdCoDO8Q4dUDCAs\&uact $=5$ 
Usman, A. M. (2013). "Governance Issues in Pakistan: Suggested Action Strategy.” ISSRA Papers , P. 113.

Ulen, T. S. (2011). The Role of Law in Economic Growth and Development. William College, Scolars' Seminar, PP. 2-40.

USCIB. Good Governance \& the Rule of Law. (2015). Retrieved: http://www.businessforpost2015.org/., PP. 3-4.

Wojtasik, W. (2013). Functions of Elections in Democratic Systems.Retrieved:

https://www.researchgate.net/publication/255965201.

French Revolution. Retrieved:

www.unishivaji.ac.in/uploads/distedu/B. A. Part-II..., 1789. 